\title{
The Series of Leaflets as Media for Education, Promotion and Monitoring of Exclusive ASI
}

\author{
Debby Yulianthi Maria ${ }^{1}$, Dwi Hariyanti², Bety Agustina Rahayu ${ }^{3, *}$ \\ ${ }^{1,2,3}$ STIKes Surya Global Yogyakarta, Yogyakarta, 53235, Indonesia \\ 1'debbyyuliathimaria@gmail.com, ${ }^{2}$ hariyanti.sg@gmail.com, ${ }^{3}$ betyagustinarahayu@ yahoo.co.id* \\ *corresponding author
}

Submission date: 13 November 2019, Receipt date: 1 Desember 2019, Publication date: 1 November 2020

\begin{abstract}
Mother's knowledge about the importance of exclusive breastfeeding is a problem that determines the success of exclusive breastfeeding. Information support is needed to increase the mother's knowledge. This research create an acceptable media for increasing mother's knowledge of exclusive breastfeeding. This research uses the action research method. There are 5 stages including diagnosis, making an action plan, acting, evaluating and learning. The informants of this research are the baby mothers, posyandu cadres and the ASI counselling team at the Pleret health centre. Data collection instruments and techniques using questionnaires and interviews. Credibility test with technical triangulation, which was analyzed using theories from Milles and Huberman. The creation of a series of leaflet media about exclusive breastfeeding guidelines consisting of six series. Leaflets are made attractive in terms of design. This series of leaflet media can be used as an educational and promotional media about exclusive breastfeeding.
\end{abstract}

Keywords: leaflet media, promotion, monitoring, exclusive ASI

\section{INTRODUCTION}

Mother's knowledge about the importance of exclusive breastfeeding is an issue that determines the success of exclusive breastfeeding. Working mothers do not have enough time to attend Posyandu activities or other extension activities. The reason for this working mother is that it causes no information to be conveyed about the importance of exclusive breastfeeding. Due to the bad baby does not get the right to obtain exclusive breastfeeding [4].

Various attempts have been taken to improve the granting of exclusive breastfeeding, one of them is health promotion. Nonetheless, the health promotion has not shown the optimal result especially on the use of media. The objective of this study was to determine the effect of health promotion regarding exclusive breastfeeding on the knowledge improvement of pregnant mothers either by using leaflet [26].

Data from the Ministry of Health of the Republic of Indonesia and Pusdatin figures for exclusive breastfeeding in Indonesia were 35.7\% in 2017 [3] [9] [10] [24]. This figure is far from the WHO recommendation, which is $50 \%$. Yogyakarta City has implemented Perda No. 1 of 2014 concerning exclusive breastfeeding. According to the city's Health Department notes, exclusive breastfeeding has doubled from 30 percent to 60 percent. In 2017, it is targeted that exclusive breastfeeding will reach up to 70 percent [1] [27]. 
From the results of preliminary studies that have been carried out there are data on 7 baby mothers who do not provide exclusive breastfeeding in the White Lotus Posyandu area of Pungkuran Pleret Bantul in 2019. The second problem comes from posyandu cadres, posyandu cadres feel they do not have enough qualifications and information to provide health education and promotion about exclusive breastfeeding.

Preliminary about Posyandu, Posyandu does not have media that is used to provide information about exclusive breastfeeding. Posyandu cadres feel they do not have enough qualifications or ability to provide counseling. Posyandu cadres feel the time to provide counseling is also less effective because there is no specific agenda, where posyandu activities are only registration, weight weighing, measurement of head and arm belly circumference, and finally supplementary feeding. So there is no special time for counseling, considering the baby's mother must also immediately go to work. Sometimes in a toddler posyandu activity, babies are delivered not by their mothers but by grandmothers or carers. This has become one of the problems inhibiting the delivery of information. This is different from the theory that should be about posyandu. Based on Posyandu activities, the organization of Posyandu is divided into 5 tables, namely: a) Table I for registration, either under-five, pregnant mother or EFA. B) Table II for toddler weighing and measurement of LILA of pregnant mother and EFA. C) Table III for the registration of toddlers, pregnant women, and PUS / WUS. D) Table IV for counselling. E) Table $\mathrm{V}$ for health services and family planning [20]

The third problem from the Pleret Bantul Community Health Center cannot always be present in the monthly activities at the Posyandu. Lack of human resources is the reason for his absence in the toddler Posyandu agenda. Achievement of exclusive breastfeeding in the Pleret Bantul region has not reached $100 \%$. The results of interviews conducted with the exclusive ASI counseling team obtained data on exclusive breastfeeding promotion activities only carried out in activities held by health centers that invite posyandu cadres, and counseling when the baby's mother comes to the nutrition room and KIA to check the child. The lack of human resources in the community health center especially in the nutrition section causes the maximum lack of exclusive ASI counseling teams to promote exclusive ASI [14]. Promotion and monitoring of exclusive breastfeeding is done by the 24-hour recall method. This 24hour recall method is performed on infants 0-6 months and 6-24 months [15] [20]. The problems presented by respondents in this study, the researchers plan to create innovative media that are interesting, effective, and efficient in the hope that they will assist the exclusive ASI primary health care counseling team or posyandu cadres in exclusive breastfeeding promotion activities. It is hoped that the achievement of exclusive breastfeeding in the work area of Pleret community health center health care will increase to $100 \%$. From preliminary study, this research appropriate if using action research method to solve existing problems. Learning media can be used as an aid that enhances thought, feeling, attention, and interest. Leaflet as learning media showed significant knowledge improvement in exclusive breastfeeding [13]. For mother baby, pictures and benefit from media can increase learning activity. Print out media consist of a leaflet [11].

\section{RESEARCH METHODS}

This research was approved by the Health Research Ethical Committee STIKes Surya Global Yogyakarta (Number: 244/KEPK/SG/VII/2019) before the data were collected. This research was conducted in Pleret Bantul Yogyakarta from of Mei to 
October 2019. This research uses an action research method. In this action research, the researcher conducted a description, interpretation, and explained the social situation to change changing behavior for good by giving an intervention. The purpose of the action research method is a problem-solving research framework [12]. Action research, as a method of inquiry, is founded on the assumption that theory and practice can be closely integrated by learning from the results of interventions that are planned after a thorough diagnosis of the problem context [2] [25]. There are five stages in action research [12] consisting of the stages of diagnosis, making an action plan, taking action, evaluating and learning. Action research refers to a wide variety of evaluative, investigative, and analytical research methods designed to diagnose problems or weaknesses whether organizational, academic, or instructional and help educators develop practical solutions to address them quickly and efficiently. Action research may also be applied to programs or educational techniques that are not necessarily experiencing any problems, but that educators simply want to learn more about and improve. The general goal is to create a simple, practical, repeatable process of iterative learning, evaluation, and improvement that leads to increasingly better results for schools, teachers, or programs. Action research may also be called a cycle of action or cycle of inquiry, since it typically follows a predefined process that is repeated over time.

The informants in this study were the mother of the baby, the cadre of the toddler Posyandu and the ASI community health center counseling team. Data collection techniques using questionnaires, observation and interviews. The questionnaire was used to collect data related to the achievement of exclusive breastfeeding in mothers of children under five. Interviews were carried out to mothers of children under five to examine the failure constraints of exclusive breastfeeding, as well as the constraints of posyandu cadre mothers and the exclusive breastfeeding counseling team at the community health center in providing exclusive breastfeeding promotions [26]. The results of the data collected will be carried out data reduction, data presentation, and drawing conclusions in accordance with Milles and Huberman's analysis. Triangulation technique was used in the credibility test of this study [21].

\section{RESULTS AND DISCUSSION}

\section{Characteristics of Baby Mothers Respondents:}

There are 7 informants who participated in this study. Respondents in this study were informants who did not exclusively breastfeed their babies. From the results of the study, the characteristics of the age of respondents were in the early adult category (2635 years) as many as 5 people (71.43\%) and late adulthood (36-45 years) as many as 2 people $(28.57 \%)$. The last education of mothers in the low education category was 4 people $(57.14 \%)$ and 3 people $(42.86 \%)$ with secondary education.

Mothers with jobs as laborers were 4 people (57.14\%), 2 people $(28.57 \%)$ as traders, and 1 person $(14.29 \%)$ as private employees. Four mothers $(57.16 \%)$ had 2 children, 1 mother $(14.28 \%)$ had 1 child, 1 mother $(14.28 \%)$ had 3 children, and 1 mother $(14.28 \%)$ had 4 children. Income of 3 mothers $(50 \%)$ conversational $<\mathrm{Rp}$ $1,000,000.00$ and 3 other mothers $(50 \%)$ between Rp 1,000,000.00 - 1,500,000.00. Six mothers $(85.71 \%)$ said they had received exclusive breastfeeding counseling, and 1 mother $(14.29 \%)$ did not. Three mothers $(42.86 \%)$ said they received breastfeeding counseling, and 4 mothers $(57.14 \%)$ did not receive breastfeeding counseling. 
Characteristics of Posyandu Cadres:

The majority of cadres were in late adulthood (36-45 years) as many as 8 people (72.72\%), and 3 people (27.27\%) entered the early elderly age (46-55 years). Last education 10 cadres $(66.67 \%)$ included in the basic education category and $5(33.33 \%)$. Characteristics of the ASI Health Center Counseling Team. There were 11 exclusive breastfeeding counseling teams at the Pleret Community Health Center. Four people (36.36\%) fall into the early adulthood category (26-35 years) and seven people (63.64\%) fall into the early age category (46-55 years). Last education 11 people $(100 \%)$ entered tertiary education consisting of midwifery and nutrition. Ten people $(90.90 \%)$ are civil servants and a freelance daily employee. $(9.10 \%)$. One person has worked for 10-20 years, 4 people worked 21-30 years, 3 people worked 31-41 years, and 3 people worked 41-50 years. One person monthly salary <Rp. 2,000,000.00, 3 people with a salary of Rp. 2,000,000.00 - Rp. 3,000,000.00, and 7 people with a salary of more than Rp. 3,000,000.00.

Action Research:

Action research is a tool that is used to help educators uncover strategies to improve teaching practices [18], it is viable endeavor for all educators. Action research may also be called a cycle of action or cycle of inquiry, since it typically follows a predefined process that is repeated over time. Stage of action research is identify a problem to be studied, collect data on the problem, organize, analyze, and interpret the data, develop a plan to address the problem, implement the plan, evaluate the results of the actions taken, identify a new problem and the last is repeat the process. The following result of action research in this study are :

The first stage:

This stage consists of diagnosing, researchers conducting surveys of problems by distributing questionnaires about the success and knowledge of exclusive breastfeeding to mothers of children under five. In addition to the survey using questionnaires for mothers of toddlers, interviews were also conducted to examine the causes of exclusive breastfeeding failure. The survey was also conducted on posyandu cadres and ASI counseling teams from the Pleret Community Health Center on the issue of the success of exclusive breastfeeding in the working area with interview techniques.

The problem that was found during the survey with the baby's mother found that there were 7 mothers out of 40 respondents who failed to give exclusive breastfeeding. The mother worked outside the home so she had to leave the child for some time. Mother feels inconvenienced to express milk at work. The existence of physical problems in the mother such as nipple is not prominent, breast milk does not come out and pain during breastfeeding is also conveyed by the baby's mother as a reason for not giving exclusive breastfeeding. Mother's knowledge about the importance of exclusive breastfeeding is an issue that determines the success of exclusive breastfeeding. The factor of working outside the home is also the reason for the failure of exclusive breastfeeding and also the cause of the absence of Posyandu activities. The reason for this working mother is that it causes no information to be conveyed about the importance of exclusive breastfeeding. Due to the bad baby does not get the right to obtain exclusive breastfeeding.

Look at the condition that there is knowledge and motivation of the mother which is the problem of not exclusive breastfeeding. The decrease knowledge and motivation about the important of exclusive breastfeeding will impact to the scope application of exclusive breastfeeding until be needed healthy promotion than can 
motivated mother for give suck in a exclusive manner requirements like utilize leaflet as information media for upgrade motivation and knowledge [16].

The second problem comes from posyandu cadres, posyandu cadres feel they do not have enough qualifications and information to provide health education and promotion about exclusive breastfeeding. Posyandu does not have media that is used to provide information about exclusive breastfeeding. Some of the reasons that became the obstacle of the community health center have not reached the target of $100 \%$ exclusive breastfeeding achievement. The results of the interviews that have been made explaining that the lack of human resources in the community health center, especially in the nutrition section, makes it less possible for the ASI counseling team to promote exclusive breastfeeding in every posyandu activity. Posyandu only provides health promotion when the baby's mother visits the community health center. Promotion and monitoring of exclusive breastfeeding is done by the 24 -hour recall method. This $24-$ hour recall method is performed on infants 0-6 months and 6-24 months.

Seeing the problems that exist, researchers devise solutions to the problems at hand. Researchers are trying to increase the mother's knowledge about the importance of exclusive breastfeeding, which hopes will change the perception, attitudes, and behavior of mothers in breastfeeding for the better [6] [7]. Researchers plan to create effective and innovative educational media [8]. Seeing the ability and condition of mothers of children under five who are still in rural areas with the majority of low and secondary education, researchers plan to compile print media in the form of leaflets that are made serially to direct mothers of toddlers to reach exclusive breastfeeding [5].

The planned media are leaflets that are made in series ranging from 1 month until 6 months. Leaflets are made with an attractive design that allows readers to read and not discard this leaflet. Besides being useful for information delivery, this leaflet will be planned in a form so that it can provide other benefits.

The second stage:

The second stage is that the researchers make a plan of action. The researchers designed the contents of the leaflet in each series. Researchers then began to design a leaflet design using the help of Corel Draw to design leaflets as expected. After the leaflet, the researchers printed out an expert test, namely the medical education specialist and nursing education specialist to provide an assessment and input on the media that has been made. Then the researchers improved the media of this leaflet according to the direction of the expert.

The third stage:

The third stage is the researchers take action. The action referred to here is that researchers begin to socialize and promote exclusive breastfeeding using serial leaflet media. Researchers worked with posyandu cadres and the ASI community health center Pleret counseling team to take advantage of this educational media as a media to promote or promote exclusive breastfeeding.

The fourth stage:

In the fourth stage, the researchers conducted an evaluation of the serial leaflet media. The evaluation was conducted by interviewing media users, namely baby mothers, posyandu cadres, and the Pleret Community Health counseling team about serial leaflet media. Evaluations include design, information content, and usefulness of leaflets. Fifteen posyandu cadres, seven baby mothers, and eleven exclusive breastfeeding counseling teams at the Pleret Public Health Center stated that this leaflet was quite interesting in terms of design, color, content and had other benefits so that 
readers felt reluctant and felt pity to throw it away. The results of interviews with respondents regarding the evaluation of this media are as follows:

"Leaflets are already attractive both in image and color. The contents are good for giving information to mothers of toddlers about the steps to pass exclusive breastfeeding every month. Can be used as a cadre guide for your counselling "(P)

"Interesting is good, it has other benefits, so it is not right if you throw it away. The contents are also good at giving an overview of ways to provide exclusive breastfeeding "(F)

"The leaflets are good, interesting, providing important information and other benefits of this leaflet, so it's a shame to throw them away. This leaflet can also provide coherent information in order to exclusively breastfeed for up to six months "(E)

The fifth stage:

The fifth stage is learning, this stage is the final part where researchers conduct a review of the stages that have been passed. At the diagnosis, stage researchers have found a problem. Researchers have also planned solutions to overcome the existing problems by creating serial leaflets aimed at increasing the knowledge of infant mothers about exclusive breastfeeding, providing media to posyandu cadres and Puskesmas counselling teams as a means of providing information. Leaflets have been made in six series according to the time of exclusive breastfeeding, leaflets containing information related to exclusive breastfeeding.

The mother of the baby who was a participant was in early adulthood and late adulthood. Mother is in a mature period both in terms of understanding and making decisions. According to Erlin (2017) the more mature a person's age the experience of his life is also more, age influences one's comprehension and mindset. Increasing age will further develop one's mindset and capture power so that the knowledge gained is also increasing [21].

The majority of working toddlers have a number of 2 children, with already having previous children, the mother has prior experience in caring for and breastfeeding her child. Similarly, the more positive aspects of the object that are known it will foster a positive attitude towards the object. Conversely, if according to Middlebrook in Azwar (2012: 31) says there is no experience possessed by someone with an object then it tends to form a negative attitude towards the object [23].

Mother of toddlers working in this study with the last education is low and secondary schools. With a monthly income of less than Rp 1,500,000. The development of increasingly fast times, in line with the increasing needs of life. Then the need for economic status also greatly influences the availability of facilities needed for certain activities in this case blushing ASI. Sources of information obtained by mothers also require costs or the economy. Information can be obtained through electronic mass media or print mass media, mothers can browse or buy reading books as a source of information, in other words, the economy also affects a person to increase knowledge.

With the presence of this series of leaflet media, it is hoped that it will help the baby's mother in increasing her knowledge. Leaflet according to Notoadmojdo (2010) is a piece of paper containing writing with short sentences, dense, easy to understand, and the tone of simple images [21]. Leaflets in Syamsiah's research (2013) affect respondents' knowledge and intentions. The leaflet media is also effective in increasing the knowledge and skills of washing hands with soap in Sang Surya female students at the Muhammadiyah University of Malang [2]. 
From the problems found in the diagnosis stage, researchers have formulated the problem of the need for increased knowledge both of the baby's mother and the posyandu cadre. Efforts to increase knowledge have been created serial leaflets about exclusive breastfeeding. In the second stage, researchers have created a 6 series leaflet, which provides information on how to achieve exclusive breastfeeding in each month.

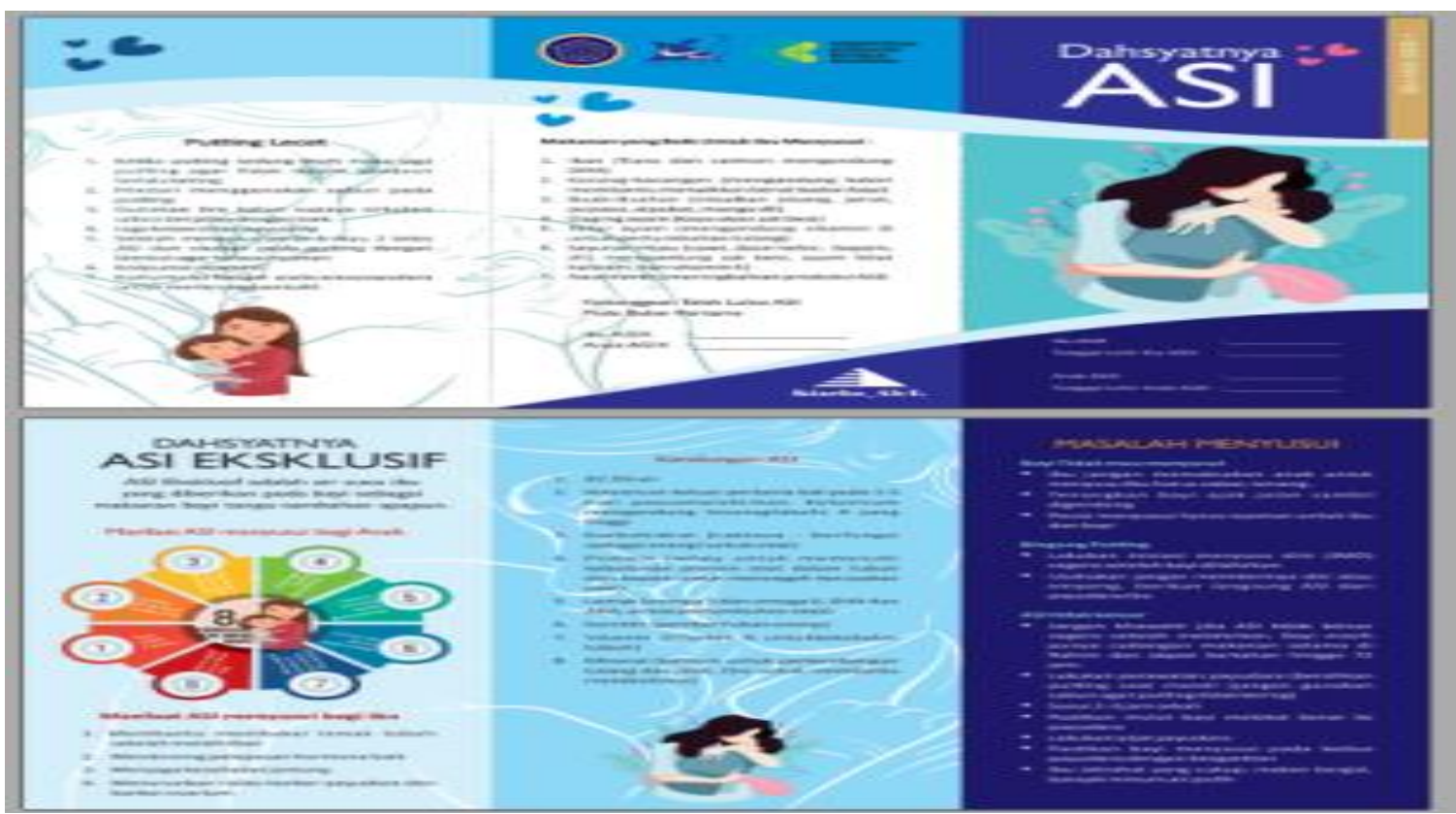

Figure 1. Serial leaflet 1

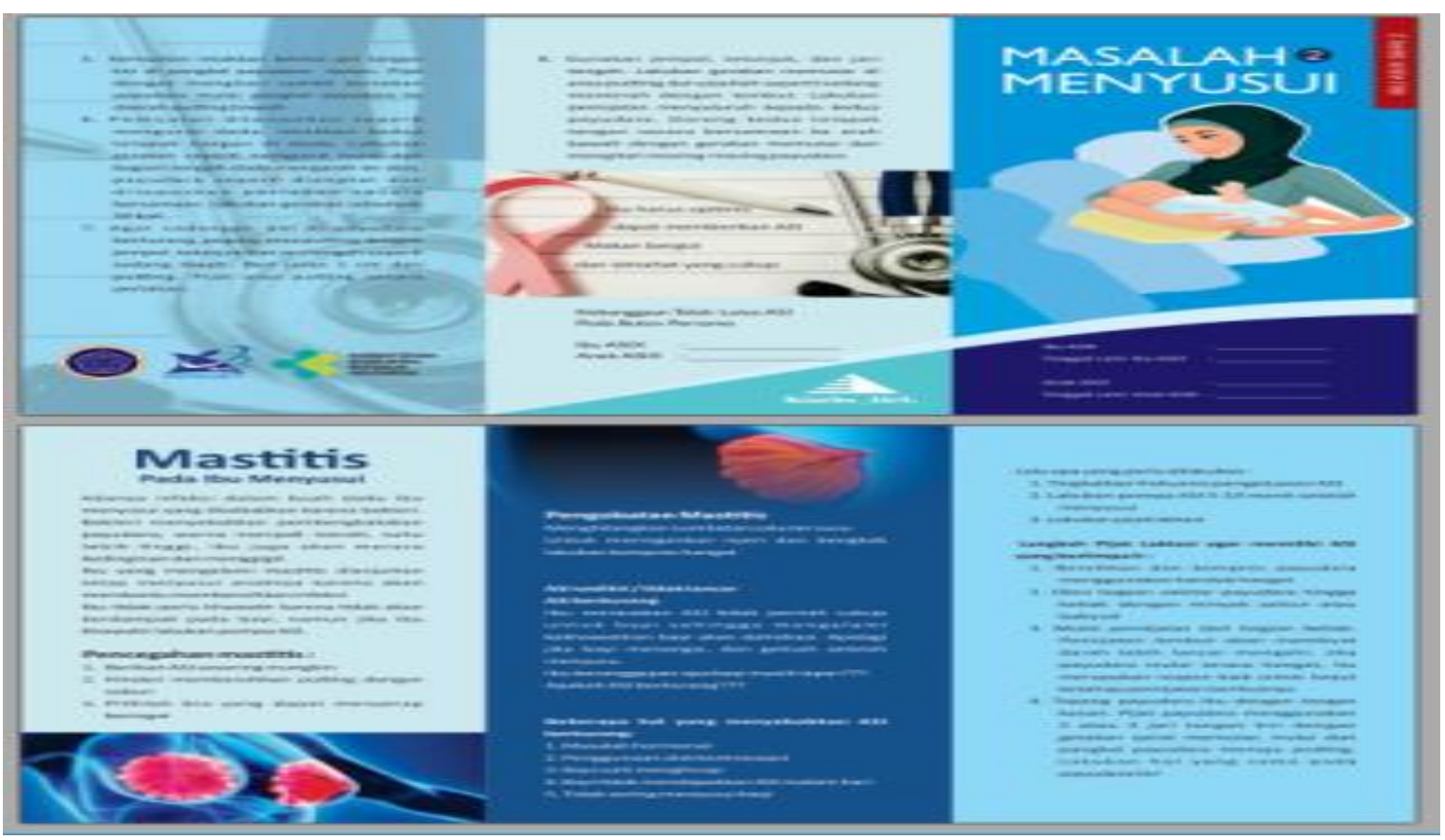

Figure 2. Serial leaflet 2 
International Journal of Health Science and Technology, 2 (2) 2020

36

Debby Yulianthi Maria, Dwi Hariyanti, Bety Agustina Rahayu

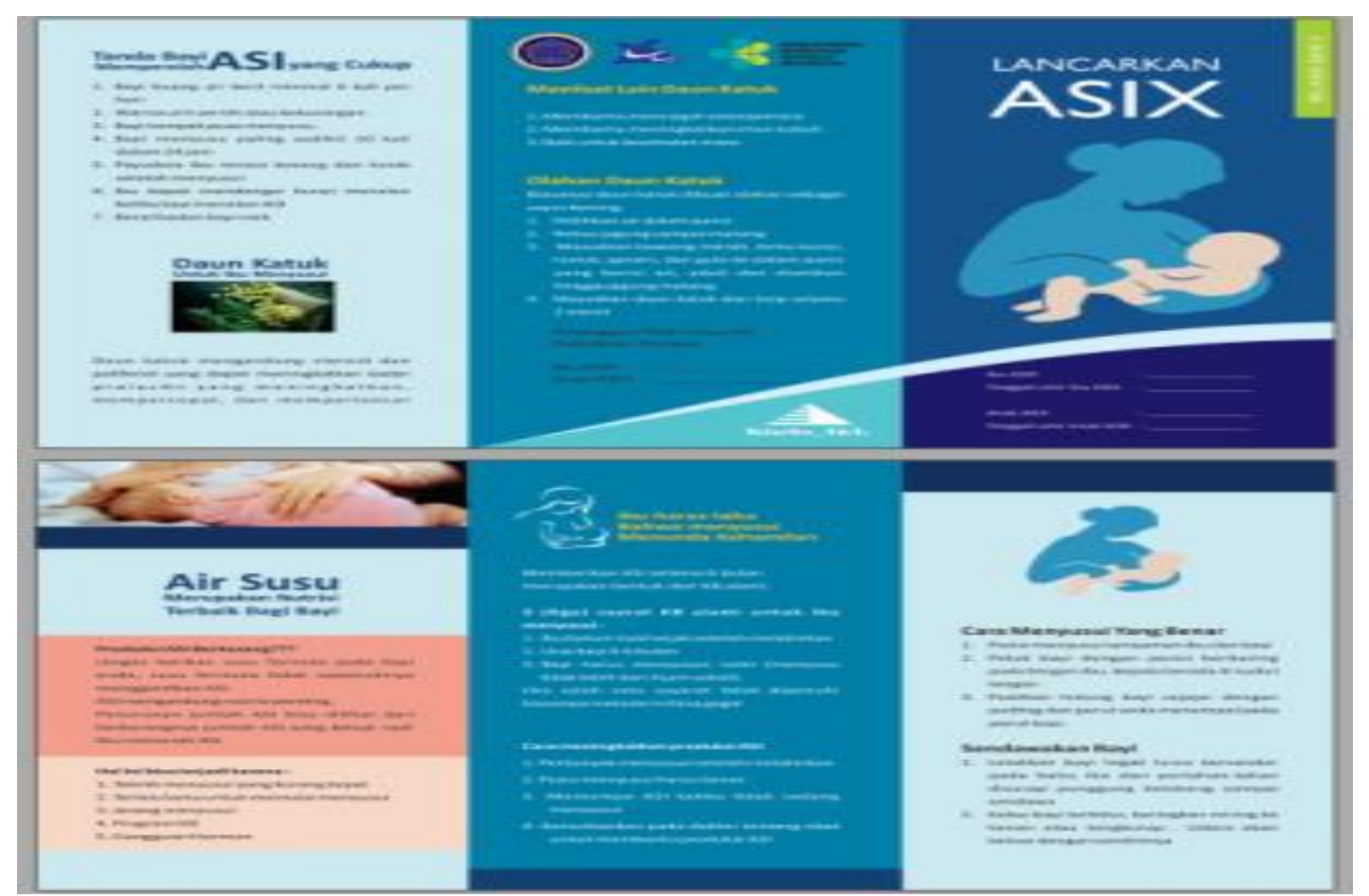

Figure 3. Serial leaflet 3

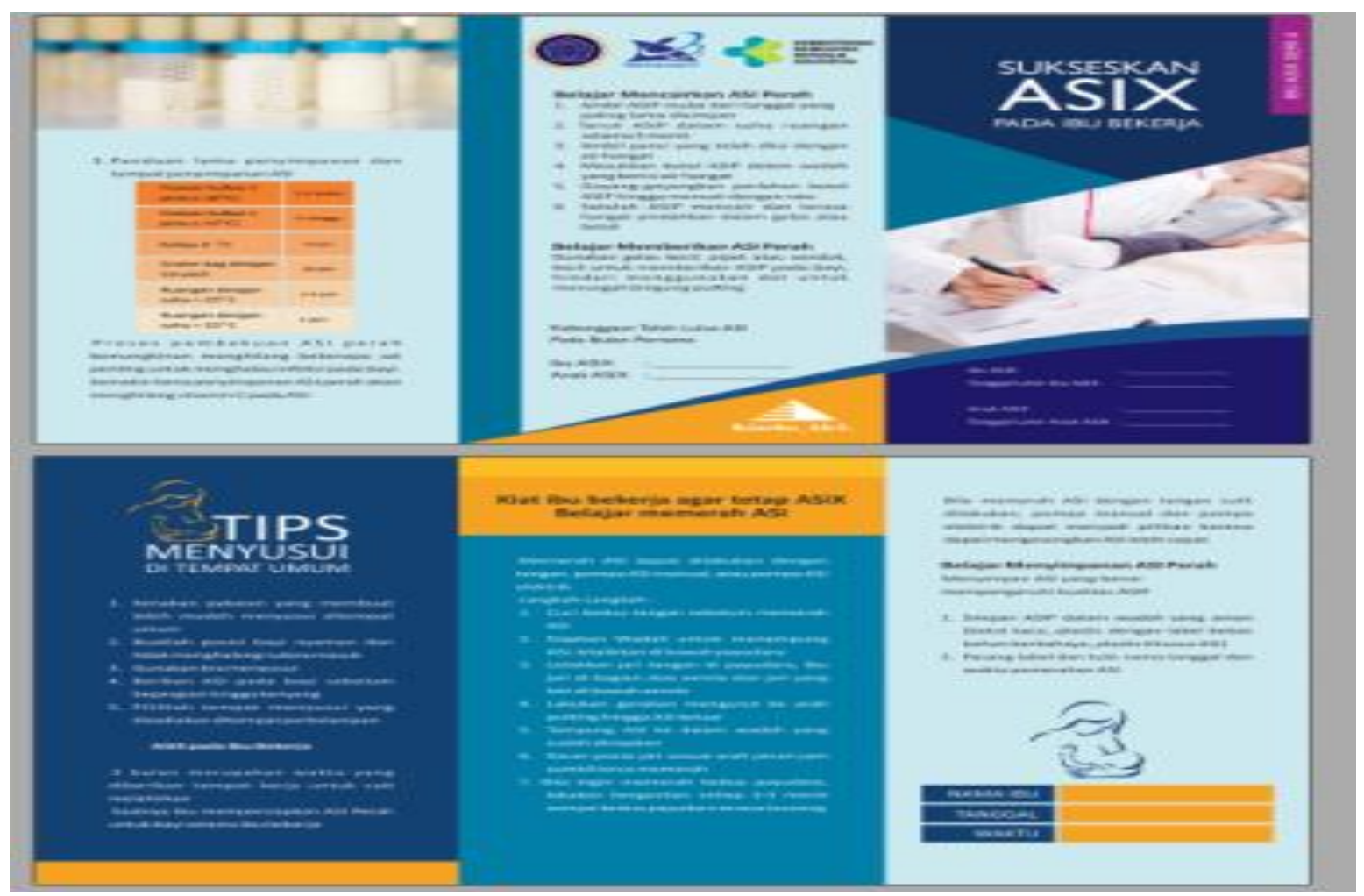

Figure 4. Serial Leaflet 4 

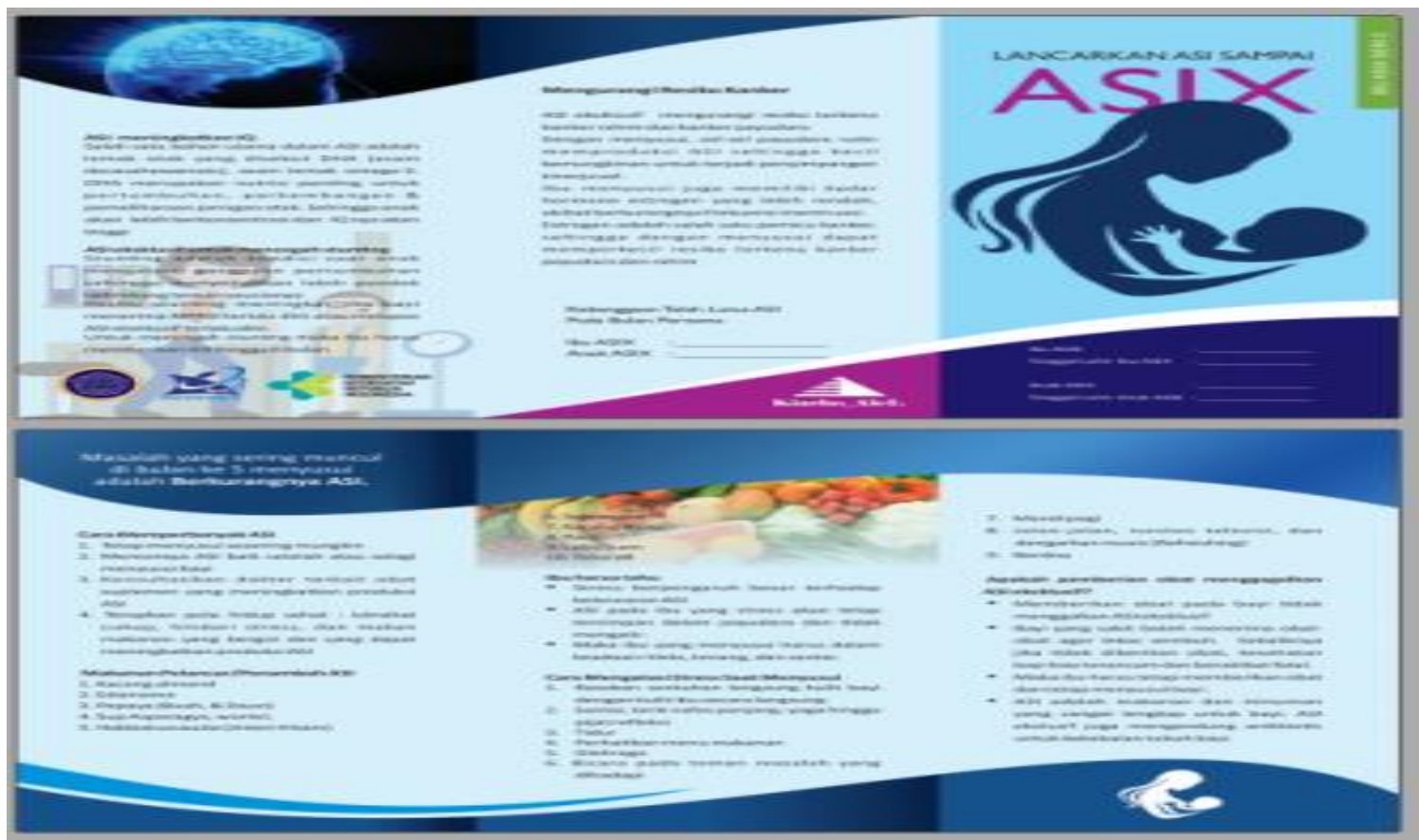

Figure 5. Serial leaflet 5

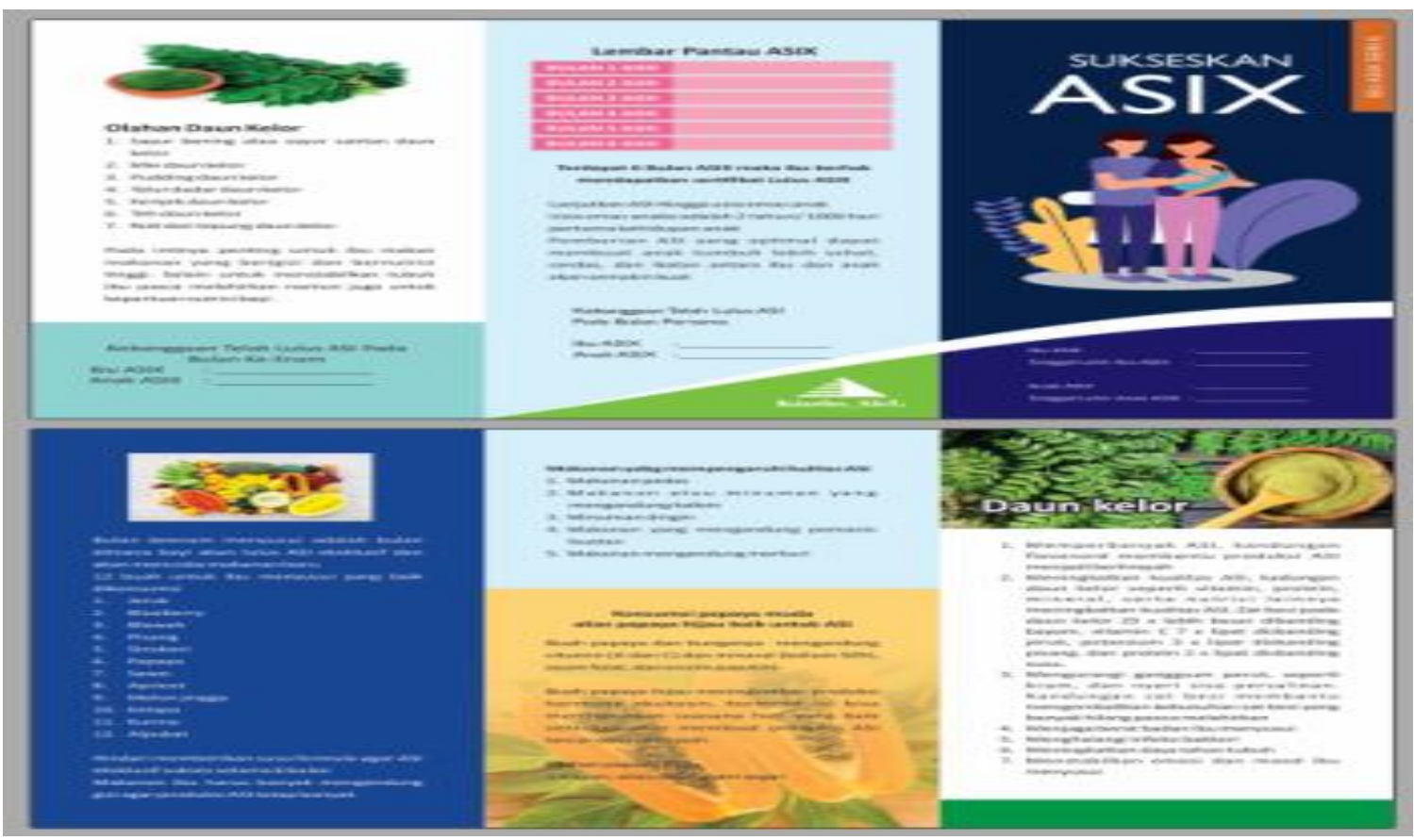

Figure 6. Serial Leaflet 6

This leaflet is designed as a healthy health card owned by each baby to monitor their growth and development. This leaflet has an identity column where this column is made so that the mother has the responsibility or obligation to provide exclusive breastfeeding to her baby. The hope is that this identity column will increase the motivation and confidence of mothers to provide exclusive breastfeeding.

The identity column contains the mother's name, mother's birthday, child's name, and the child's birthday. The child's date of birth must be in accordance with the 
serial leaflet. Children who are at the age of 1 month then the mother should hold the series 1 leaflet, if the baby is 2 months old the mother must write and hold the series 2 leaflet and so on. Mothers with babies at 2 months should have series 1 and 2. Mothers with babies at 3 months should have series 1,2, and 3 and so on. So if the baby is 6 months old, the mother has all the serial leaflets.

In the series 1 leaflet with the title of the enormity of the ASI series. This leaflet series 1 provides information about the benefits of exclusive breastfeeding for babies and mothers, the content of breast milk, problems that are often experienced in nursing mothers in the first month and its handling, and good food for nursing mothers.

Series 2 leaflet with the title breastfeeding problems in the second month and how to overcome them. Series 3 leaflet with the title ASIX, ASIX is a term that is made with the meaning of "Exclusive" ASI-X or A-SIX which is ASI "6 months". This series provides information about ways to facilitate breastfeeding and the benefits of breastfeeding in contraception.

The fourth series of this leaflet is titled ASIX success in working mothers. Considering the baby's age of four months is a period in which the working mother has finished passing her maternity leave rations. In this series, some information is provided for working mothers to be able to provide exclusive breastfeeding. The information provided includes how to express milk, store breast milk, dilute milk and give milk to babies.

The fifth series in this leaflet is titled ASI to ASIX, the purpose of this 6th leaflet is to provide information so that mothers can continue to give breast milk for at least 6 months. In this series tips on multiplying breast milk, smoothing breast milk and additional information about the benefits of breast milk are conveyed in detail. The sixth session is the last series with the title ASIX success. Considering that breastmilk for working mothers there must be a change in the volume of milk produced, so in this series is given information about supplementary foods that help increase breast milk.

In each leaflet in addition to containing information that is one of the benefits of the leaflet, namely as a media to promote education about exclusive breastfeeding, this leaflet has a column of monitoring sheets in each series in the pride column and at the end of the sixth series which is a sheet of monitoring ASI for up to 6 months .

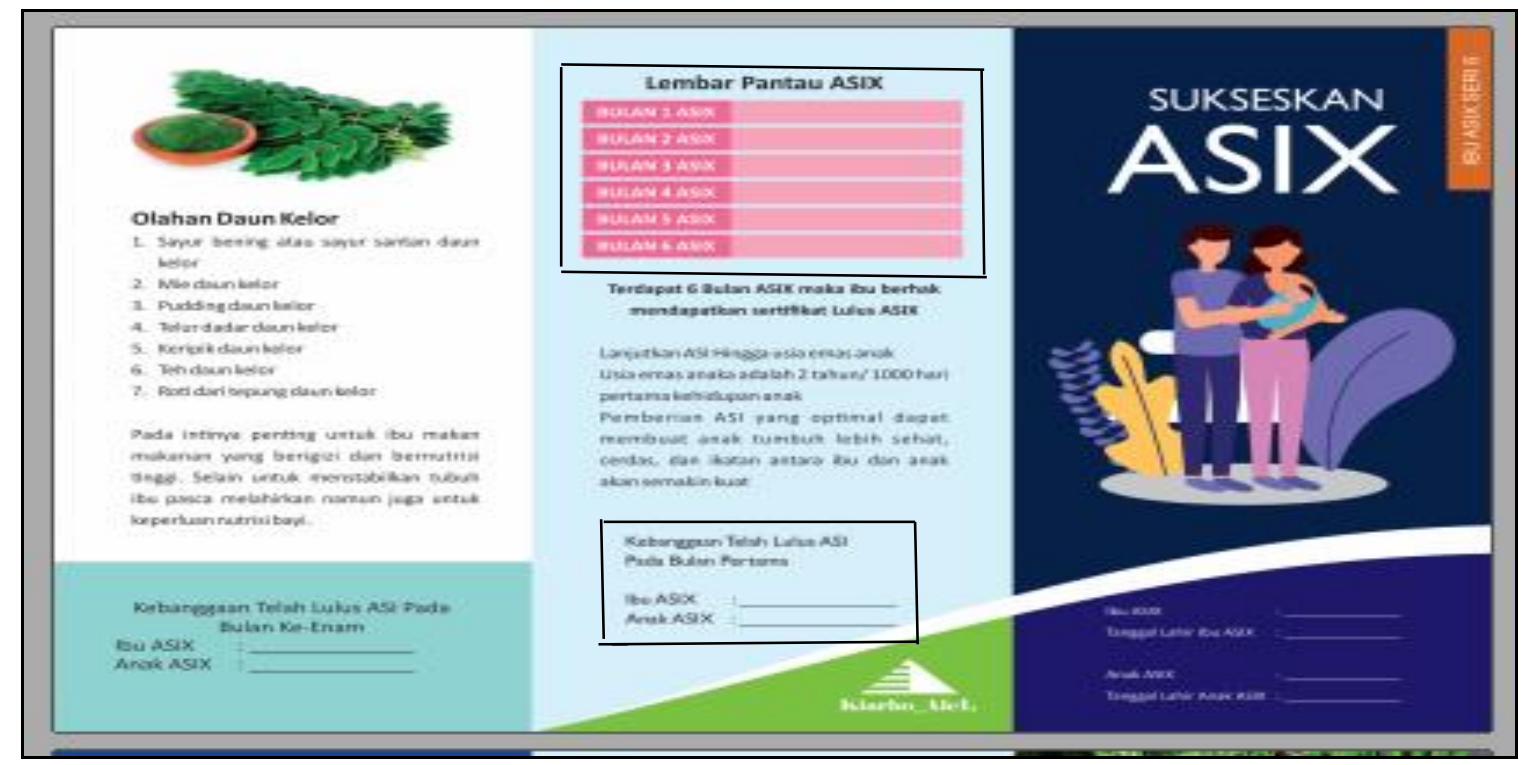

Figure 7. Monitoring Sheet 
Mothers who have passed exclusive breastfeeding will get a certificate of passing ASI. This certificate is only given to mothers who have successfully breastfed for 6 full months for their babies.

Returning to work is a common reason for stopping breastfeeding or for deciding not to start breastfeeding, however services can inform mothers that the provision of breast milk can be supported in their Service. A leaflet is a little book or a piece of paper containing information about a particular subject [16].

Result of this research is a serial leaflet. This leaflet has been revised in accordance with expert input regarding the contents and color of the leaflet. In the third stage the researchers distributed leaflets to the posyandu cadres and the exclusive ASI counseling team at the Pleret community health center, researchers also conducted and conducted exclusive breastfeeding education using serial leaflet media. Researchers worked with posyandu cadres and the ASI Pleret community health center counseling team to take advantage of this educational media as a media to promote or promote exclusive breastfeeding.

In the fourth stage, the researchers conducted an evaluation of the serial leaflet media, and the results were quite satisfying, posyandu cadres, mothers of toddlers, and exclusive breastfeeding counseling teams agreed and would use the serial leaflet media as a media to promote and monitor exclusive breastfeeding. This leaflet has been evaluated to provide benefits including: content providing information about exclusive breastfeeding, leaflet media can be used as educational promotion media and leaflet media are designed to have sections or columns aimed at monitoring exclusive breastfeeding. In final fourth stage, the researcher felt there were no significant obstacles in carrying out the stages of each of the research processes.

The existence of this innovative leaflet media provides additional motivation for mothers of toddlers in achieving exclusive breastfeeding for their baby. Mothers get knowledge about the benefits and importance of breast milk for their babies, mothers get information what if the child is not given exclusive breastfeeding, mothers get information on how to smoothen breast milk and overcome problems that might occur in nursing mothers.

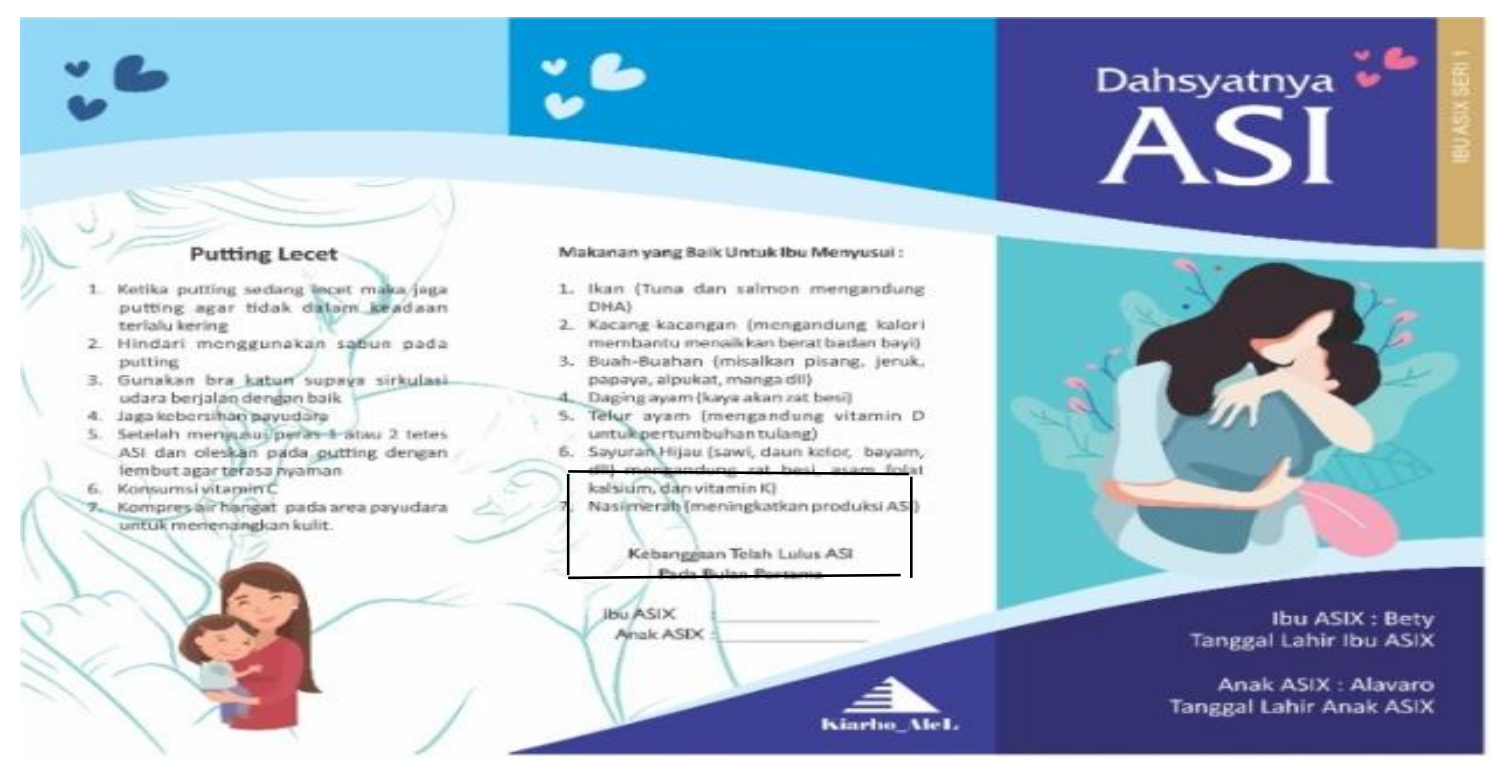

Figure 8. Pride Column 
This is an example of a pride column which is an innovation of this leaflet. Mothers will be encouraged to provide exclusive breastfeeding so that they can fill the pride column for giving exclusive breastfeeding to their children. Mother have the right to write in the column if you have given exclusive breastfeeding for the month according to the series. This indirectly has a positive impact on achieving exclusive breastfeeding in Indonesia.

Various studies have recognized that the educational media, leaflets, have a positive impact on increasing the reader's knowledge. The use of leaflets in this action research is due to the analysis of knowledge and income sources or economics that is in the sufficient category. So that the leaflet is considered the right media to be used for education about exclusive breastfeeding, with the addition of content or innovation in it.

Learning is the fifth stage, this stage is the final part where researchers conduct a review of the stages that have been passed. Problem knowledge is found this research. Creating serial leaflets is solutions to overcome the existing problems. This serial leaflets providing media to mother baby, posyandu cadres and Puskesmas counseling teams as a means of providing information. Leaflets have been made in six series according to the time of exclusive breastfeeding, leaflets containing information related to exclusive breastfeeding.

With this action research research, it has helped working mothers, posyandu cadres, and Puskesmas counseling teams to improve the achievement of exclusive breastfeeding for working mothers in the Posyandu Teratai Putih area of Pungkuran Pleret Bantul. This leaflet provides the right information for nursing mothers. So it can be said this media can be used for health promotion related to exclusive breastfeeding. This leaflet can also provide benefits to monitor or monitor the achievement of exclusive breastfeeding in nursing mothers. So in addition to the 24-hour recall method used by the puskesmas, the puskesmas also gets valid data from the mother every month regarding exclusive breastfeeding which is also monitored by the cadre of the under-five Posyandu.

This leaflet is a media for connecting information from mothers, posyandu cadres and puskesmas in collecting data on exclusive breastfeeding. Seeing the good results of this study, it is hoped that this media can be utilized by posyandu or other community health work areas. Researchers can then develop additional information content or other information updates to improve the achievement of exclusive breastfeeding.

This result of research same with Katherine, 2014 [11] action research is a tool for improving teacher quality and classroom practice. Action research involves actively participating in a change situation, often via an existing organization, whilst simultaneously conducting research [17].

\section{CONCLUSION}

Series leaflets can be used as an educational media for the promotion and monitoring of exclusive breastfeeding. An increase in the number of mothers giving exclusive breastfeeding is observed in this media leaflet. Researchers can then add other useful content to improve the achievement of exclusive breastfeeding for working mothers in this leaflet. 


\section{REFERENCES}

Agung, 2017. Pemberian ASI Ekskluisf di Kota Yogyakarta Capai 70 Persen. Diperoleh dari https://tirto.id/pemberian-asi-eksklusif-di-kota-yogyakarta-capai-70-persencnQo

Avison, D.E. (2002) Action research: a research approach for cooperative work. Proceedings of the Conference on Cooperative Systems for Cooperative Work, Rio de Janeiro

Budijanto, D. (2018). Data dan Informasi Profil Kesehatan Indonesia 2017. Indonesia.

Davison, R.M. (2001) GSS and action research in the Hong Kong Police. Information Technology and People, 14, 60-77

Demirtas, B. "Strategies To Support Breastfeeding: A Review." International Nursing Review, vol.59(4), pp. 474-481, 2012

Ditamarte L. The Influence of Nutrition Counseling on Mother Knowledge About Toodler Nutrition In Argotirto Village, Malang Regency. Departemen of FashionFaculty of Enginering UM 2012

Doddy. 2017. The Effect of Community Education Using Media Leaflet, Poster and Pocket Book Towards Posyandu Cadre Knowledge on Children Development and Growth, Supplementary Feeding, Iodine Deficiency Disorder and UPGK. International Journal of Science and Research (IJSR) ISSN (Online): 2319-7064 Index Copernicus Value (2015): 78.96 Impact Factor (2015): 6.391 Volume 6 Issue 8, August 2017 www.ijsr.net Licensed Under Creative Commons Attribution CC BY

Fine, Michelle. (2018) Just Research in Contentious Times : Widening the Methodological Imagination. Teacher College Press.

IDAI. (2015). Sukses Menyusui Saat Bekerja. Retrieved from http://www.idai.or.id/artikel/klinik/asi/sukses-menyusui-saat-bekerja-2

Idayati, T., Anggoro, S., Amry, R. Y., \& Rahayu, B. A. (2019). Hubungan Pengetahuan, Sikap dan Perilaku Pengasuh Bayi Tentang Manajemen ASI Perah Di Daycare Wilayah Pleret Bantul Yogyakarta. Cakra Medika, 6(01), 1-53.

Katherine A O'Connor (2014). Action Research : A Tool for Improving Teacher Quality and Classroom Practice at : https://www.reseachgate.net/publication/234749663

Kock. (2004). Principles of canonical action research. Info Systems J (2004) 14, 65-86

Mona, Delli et all. (2018). Leaflet and pocketbooks an education tool to change level of dental health knowledge. Bali Medical Journal (Bali Med J) 2018, Volume 7 Number 3 : 760-763 P-ISSN 2089-1180. E-ISSn 2302-2914

Mufdlilah. (2017). Kebijakan Pemberian Asi Eksklusif: Kendala Dan Komunikasi (Pertama). Yogyakarta: Nuha Medika.

Muslikha. (2011). Role Of Exclusive ASI Leaflet for Mother Knowledge About Exclusive Assets and Motivation for Exclusive Assessing in BPS Ny Djuwedah Kebasen Banyumas District

Noughabi, Z.S,Golian Tehrani, A.R. Foroushani,F. Nayeri and A. Baheiraei. "Prevalence And Factors Associated With Exclusive Breastfeeding At 6 Months Of Life In Tehran: A Population-Based Study." Eastern Mediterranean Health Journal,vol.20(1),pp.24-32, 2014

Southern NSW Local Health District, (2015). Encouraging \& supporting Breastfeeding in Child care Resource kit : http://thespoke.earlychildhoodaustralia.org.au/wpcontent/uploads/2015/11/EncouragingSupportingBreastfeedingInChildcareResource Kit.pdf 
Rowell, Lonnie L et all, (2015). Action researchers perspectives about the distinguishing characteristic of action research : a Delphi and learning circles mixed-methods study. Educational Action Research.

Sagor, R (2004). The action reaserach guidebook: A four-step process for educators and school teams. Thousnd Oaks, CA :Sage

Sandra, F., \& Ahmad, S. (2009). Penyebab Keberhasilan dan Kegagalan Praktik Pemberian ASI Eksklusif. Jurnal Kesehatan Masyarakat Nasional, 4(3), 1-12.

SIMKES UGM. 2008. Action Research / Penelitian Tindakan.Diperoleh dari : https://chandrax.wordpress.com/2008/07/05/action-research-penelitian-tindakan/. Diakses pada 10 September 2019

Gunarsa SD. Basic Theory of Child Development : Jakarta 2008

Sudjana N. Teaching Media. Bandung : Sinar Bayu Algensiondo Pffset : 2007

Sutarjo, U. Su. (2018). Profil Kesehatan Indonesia 2017.

Sykes, A. Judith. 2002. Action Research : A Praticial Guide For Transforming Your School Library. Colorado : Libraries Unlimited

WHO \& UNICEF. (2015). Breastfeeding Counselling A Training Course : https://www.who.int/maternal_child_adolescent/documents/pdfs/bc_participants_m anual.pdf

World Health Organization. (2010). Framework for Action on Interprofessional Education \& Collaborative Practice. Practice, 1-63.https://doi.org/10.1111/j.17411130.2007.00144.x. 